\title{
The Effect of Megaprojects on the Percived Image of Country of Origin in Case of Ethiopia
}

\author{
Mulugeta Girma $^{1} \quad$ Dr. Manjit Singh ${ }^{2}$ \\ 1.Ph.D. research scholar at Punjabi University, Patiala, India \\ 2.professor, University School of Applied Management Punjabi University, Patiala, India
}

\begin{abstract}
Megaprojects that cost a billion dollars or more, attracts a lot of public attention. Because of substantial impacts on the environment, budgets, economy, and society that changes the structure of society as opposed to smaller and more conventional projects it attracts media converge. Hence, it brings an extraordinary impact on the host country in terms of investment; visitor's expenditures and build a positive image by increasing nation capacity and attractiveness. Therefore, this paper appraises the impact of megaprojects on products produced in Ethiopia as perceived by foreigners taking 400 respondents. The results reveal that mega projects existed in the country were significantly affecting the product produced in the country.
\end{abstract}

Keywords: Megaproject; country of origin effect; public; media; image; conventional projects

DOI: $10.7176 /$ CER/11-2-04

Publication date:March $31^{\text {st }} 2019$

\subsection{Introduction}

Product's country of origin has implications for the product's evaluations that extend beyond product attributes. Specifically, consumers may form positive or negative feelings towards a country based on cultural, political, historical or economic factors [1]. These feelings, though unrelated to the product performance, may influence consumers' evaluations and purchase intentions of the products originating from the target countries which finally affect the country's image [2]

A country's image is an important tool used in judging the country's position in the international system and enables a nation to achieve a more advantageous position in global economic and political competition [3]. A good image translates to respect, influence and prestige and it's clear that a home country with strong, positive and universally recognized associations of trust, quality and integrity is a major advantage to its manufacturers as they face the harsh realities of global competition [4].

A positive national image may influence other nations' foreign policies to favor a country, increase revenues from trade, and draw tourists and foreign investment. In a bid to achieve these benefits, many governments are actively practicing international public relations to improve their national images throughout the world[5].

Third world countries need to craft a positive image to the west for many reasons, among which concerns, sustainable economic development are more prominent [6]. Hence, Governments and countries are beginning to employ branding and marketing techniques to sell their countries. Of which Ethiopian can be mention with the investment of building Mega projects that designed to ambitiously change the structure of society, as opposed to smaller and more conventional projects and have impact on country output and the overall image is significant[7-8]. Hence, this research will investigate those projects impact on product image produced by the county

\subsection{Literature review}

Introduction

Purchase decisions are affected by the feelings, ideas, and attitudes of consumers related to the brand's image of a given country [9]. Image considerations guide purchase choice and attitudes towards a nation determine consumer's intention to acquire the nation's products and such linkage between purchase intention and attitude by the 'theory of reasoned action by predicting the behavior of human beings [10].

human beings are usually quite rational and make systematic use of the information available to them to decide whether to engage or not engage in a given behavior.[10] Accordingly, human behavior can be predicted from a sequence of linked cognitive constructs, i.e. beliefs, attitudes, intentions, behaviour and such set of beliefs about an object's attributes affects attitudes towards the object which defined as an overall evaluation of a concept or object, such as an issue, person, group, brand, or service, which enables one to respond in a consistently favourable or unfavourable manner towards a given object [11].

Attitude, behavioral intentions are affected by 'subjective norms', that defined as the person's perception of the social pressures put on him/her either to comply with the wishes of others or not that causes volitional behaviors, such as the actual purchasing and consumption of products and or service form a given brands [12]. Attitudes and subjective norms are treated as independent predictors of intentions in the theory of reasoned 
action and it views a person's intention to perform or not to perform a given behavior as the immediate determinant of the action [11]. Hence, attitudes should always predict intention despite various events such as personality traits, attitudes towards people, attitudes toward institutions, or demographic variables can intervene between the measurement of intention and the observation of behavior.

To study how mega projects affect the nation's outputs, Part of the theory of reasoned action with modification. i.e. external variables in this research, case (megaprojects) beliefs to consider for purchase made in Ethiopia (consideration); attitude toward making in Ethiopian products and preferences; intention to purchase and pay more for made in Ethiopian products, was used as a framework to construct the theoretical model.

Beliefs are translated into beliefs about made in Ethiopia products with consideration, which leads to a favorable or unfavorable attitude, as represented by preference with outputs'. The intention is translated into 'intention to consume outputs and interest pay more for made in Ethiopia' in the theoretical model. The mega projects that affect the overall national image are regarded as an external variable, bearing an indirect effect on the 'intention to consume made in Ethiopia products by affecting the beliefs and attitudes towards the made in Ethiopia products or services. Therefore, the research is designed to determine the impact of megaprojects on export dimensions of the overall national image that are most frequently associated with made in the labels that affect the consumer's decision process.

\subsection{Methodology \\ 3.1. Sampling}

The data were collected in Addis Ababa over a time span of eight weeks between January and February 2018, choosing randomly one day per week for a total of eight data collection days. The sample consisted of international visors that were in Ethiopia at the time. The self-administered questionnaires were distributed to a convenience sample in places heavily populated by foreigners in the main city and shopping area of the country. A total of 450 questionnaires were distributed taking Morgan (1976) sampling techniques. From the 419 questionnaires collected, 19 were not usable. Thus, a total of 400 questionnaires were coded for data analysis. The result shows the country was visited by tourists who came from seven continents. Majorities of the respondents $(60 \%)$ were younger than 45 years old, and $44.4 \%$ were female. Approximately $79.8 \%$ of the respondents had a post-secondary degree (i.e. college, university or equivalent degree). Almost half of the respondents were coming to Ethiopia for the first time $(47.8 \%)$, while the remainder were returning (second visit or more), and $78 \%$ were in Ethiopia for the conference, while the $22 \%$ for business, leisure, and another purpose.

\subsection{Instrument}

The questionnaire consisted of five major sections. The first section was developed to assess each respondent's beliefs towards made in Ethiopia that initiates considerations. The second section address attitude toward made in Ethiopia products. The third section asked respondents' intention to pay more for made in Ethiopia and the recommend product for others. The items were 5-point Likert-type scale, 1 very low; 5 very high). The fifth section asked respondents' awareness of the impact of mega-projects and the impact of the mega projects on their beliefs, attitudes, and intention to make in Ethiopia products or services.

\subsection{Data analyses}

Factor analysis and structural equation modeling were used to examine the impact of mega projects on the underlying dimensions of the belief, attitude and intention dimension of export. Several fit indexes such as CMIN/DF CFI, GFI, and RMSEA were employed to assess the degree to which the measurement model fit the observed data as suggested by Hair et.al (2014) and Dyer et.al. (2007).

The cut of criteria employed in this study was 3 to 1 for the ration of chi-square to the degree of freedom (CMIN/DF). Values greater than .90 for the comparative fit index (CFI) and goodness of fit index (GFI) and a value less than 0.008 for root mean square (RMSEA) considered as acceptable respectively.

\subsection{Data analysis and discussion}

\subsection{Factor analysis country of origin}

FA that determines the suitability of data conducted in this study because it is structural equation modeling prerequisite. Meanwhile, the sample size and the factorability of the correlation matrix checked. Meanwhile, the KMO value for consideration, preference, and interest to acquire, consume and pay for made in Ethiopian products was .885 and significant at $\mathrm{p}=0.000$. Hence, it is possible to run for SEM analysis because both assumptions, KMO should be above .05 and the correlation matrix at least some of coefficient $\mathrm{r}$ is greater than 0.3 were addressed well [13]

Three factors with eigenvalues above.70 generated, that explains 94\% of the total variance (see Table 1). The communalities varied from 0.50 to 0.999 , suggests that the variance in each original variable reasonably explained by the three common factors. The factor loading for the 17 variables ranges from .910 to .990 , were 
above the suggested threshold value of 0.30 for practical and statistical significance. The loadings also presented a clean and highly interpretable solution. The 17 variables loaded significantly on three factors as the researcherconceptualized consideration for made in Ethiopia products, preference for made in Ethiopia and interest to pay more for made in Ethiopia products and no variables loaded on more than one factor. The Cronbach's Alphas that shows internal consistency among the variables for the seven factors were robust, ranges from 0.784 to 0.984 that was well above the generally agreed lower limit of 0.60 for research at the exploratory stage. Hence, the entire three factors were significant to run SEM analysis. (See table.)

\begin{tabular}{|c|c|c|c|c|c|}
\hline Table 1. Factor analysis output for the es & port dim & ision of nat & ion bran & ling & \\
\hline Kaiser-Meyer-Olkin Measure of Sampling Adequacy. & & & & & .885 \\
\hline Approx. Chi-Square & & & & & 7686.27 \\
\hline Df & & & & & 28 \\
\hline Sig. & & & & & .000 \\
\hline & $\begin{array}{l}\text { Engine } \\
\text { value }\end{array}$ & $\begin{array}{l}\% \text { of } \\
\text { Variance }\end{array}$ & $\begin{array}{l}\text { Factor } \\
\text { oading }\end{array}$ & $\begin{array}{c}\text { Comun } \\
\text { alites }\end{array}$ & $\begin{array}{l}\text { Cr.Alph } \\
\text { a }\end{array}$ \\
\hline Consideration & 12.893 & 80.582 & & & .984 \\
\hline I can recognize brand names from Ethiopia. & & & .948 & .900 & \\
\hline Products produced in Ethiopia are reliable. & & & .964 & .932 & \\
\hline This country has a free-market system. & & & .964 & .932 & \\
\hline This country has a high level of industrialization. & & & .963 & .929 & \\
\hline $\begin{array}{l}\text { I perceive that the country contributes to science and } \\
\text { technology. }\end{array}$ & & & .973 & .952 & \\
\hline $\begin{array}{l}\text { Preference } \\
\end{array}$ & 1.256 & 7.848 & & & .981 \\
\hline I Feel good buying products from Ethiopia. & & & 960 & .903 & \\
\hline I trust Ethiopia as a producer of any types of products & & & .950 & .880 & \\
\hline $\begin{array}{l}\text { Products produced in Ethiopia have consistent and good } \\
\text { quality. }\end{array}$ & & & .938 & .930 & \\
\hline $\begin{array}{l}\text { I feel that the country offers different technological } \\
\text { products. }\end{array}$ & & & .964 & .901 & \\
\hline If this country were a brand, it'd be my favorite brand. & & & .969 & .944 & \\
\hline If this country were a brand, I would be loyal to it. & & & 949 & .921 & \\
\hline Interest & .747 & 4.666 & & & .730 \\
\hline The country offers good value for the money I spent. & & & .969 & .940 & \\
\hline If this country were a brand, I would pay more for it. & & & .960 & .910 & \\
\hline $\begin{array}{l}\text { I think mega projects will improve the perception of } \\
\text { science and technology of the country. }\end{array}$ & & & .960 & .921 & \\
\hline $\begin{array}{l}\text { Megaprojects help me to believe in made in Ethiopia } \\
\text { products }\end{array}$ & & & .990 & .998 & \\
\hline $\begin{array}{l}\text { I think Megaprojects have an impact on changing } \\
\text { products a global image of this country }\end{array}$ & & & .992 & 999 & \\
\hline $\begin{array}{l}\text { Extraction Method: Principal Component Analysis. } \\
\text { Rotation Method: Varimax with Kaiser Normalization. }\end{array}$ & & & & & \\
\hline a. Rotation converged in 3 iterations. & & & & & \\
\hline
\end{tabular}

\section{Source: - Own survey 2018}

\subsection{Structural equation modeling for COO vs. nation branding: maximum likelihood model}

The result of the structural equation model for the measurement models of all the three constructs of export dimensions of nation branding .i.e. perceived consideration, preference and interest to acquire, consume and pay for made in Ethiopia products presented under here. The analyses evaluated in terms of the TLI and the CFI measures of fit and the significance of the estimated coefficients, squared multiple correlation coefficient, composite reliability and average variance extracted are significantly associated with their observed variables because all the estimation parameters of those variables are acceptable for the sum up the effect of export dimension.

\section{Source: - Own survey 2018}

The model estimation result shows all the measures were acceptable with the chi-square $\left(\mathrm{x}^{2}\right)$ value of 2.276 , root mean square estimation error (RMSEA) value of .000, comparative fit index (CFI) value of 1.000 and the Normed fit index of (PNFI ) value of 1.000, Tucker-Lewis index (TLI) value of 1.000. All were above the 
threshold value that existed in different research and statistical criteria.

\begin{tabular}{|c|c|c|c|c|c|c|c|}
\hline \multicolumn{7}{|c|}{ Table 4. The export dimension with sum up effect of mega projects } & \\
\hline & & & Estimate & S.E. & C.R. & $\mathrm{P}$ & \\
\hline preference & $<---$ & Megaprojects & .469 & .005 & 99.250 & $* * *$ & Accepted \\
\hline Consideration & $<<--$ & Megaprojects & .322 & .030 & 10.718 & $* * *$ & Accepted \\
\hline consideration & $<---$ & preference & .323 & .063 & 5.144 & $* * *$ & Accepted \\
\hline interest & $<---$ & Megaprojects & .099 & .024 & 4.106 & $* * *$ & Accepted \\
\hline interest & $<--$ & consideration & .467 & .035 & 13.195 & $* * *$ & Accepted \\
\hline interest & $<--$ & preference & .324 & .046 & 7.074 & $* * *$ & Accepted \\
\hline $\mathrm{mg}$ & $<--$ & preference & .036 & .026 & -1.380 & .017 & Accepted \\
\hline $\mathrm{mg}$ & $<--$ & consideration & .054 & .027 & $-1.970 \mathrm{a}$ & .049 & Accepted \\
\hline $\mathrm{mg}$ & $<--$ & interest & .089 & .033 & 2.739 & .006 & Accepted \\
\hline
\end{tabular}

Source: - Own survey 2018

The total effect of mega-projects on preference to made in Ethiopia to govern the country had a value of .459. Meanwhile, mega projects had a direct effect on the consideration of Ethiopia made in Ethiopia products during purchase decision with a coefficient of .332. Finally, interest to pay for made in Ethiopia had the coefficient of .323 and significantly affected by mega projects existed in Ethiopia. Hence, the entire construct fit the minimum threshold of .3 and shows mega projects affect the three construct of the export dimension of nation branding.

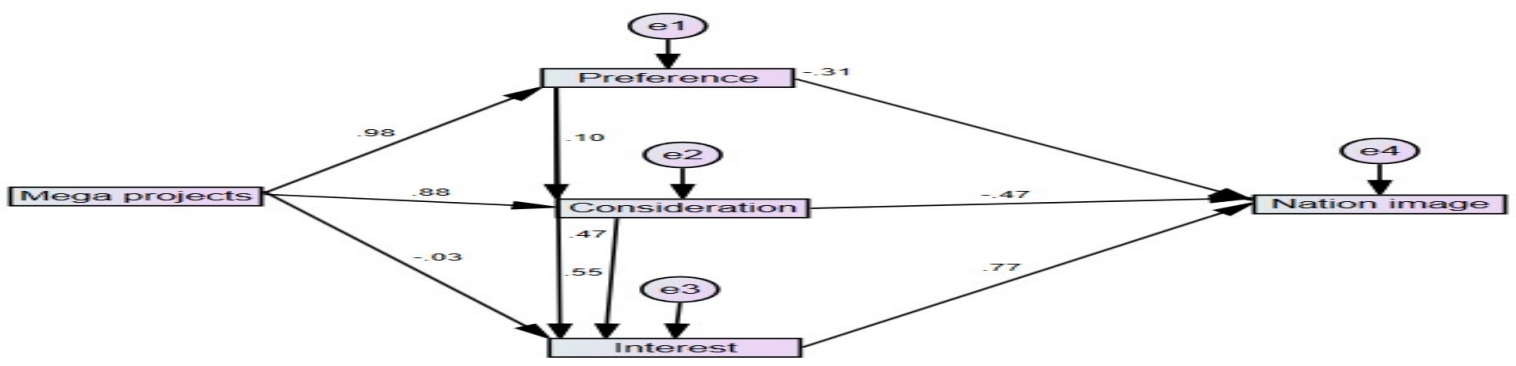

Fig. 1. The COO dimension of nation branding with sum up effect of mega projects

Source: - Own survey 2018

\section{Conclusion and recommendation}

The finding shows, mega projects affect perceived preference, consideration, and interest to purchase or acquire product produced by the country. Beside it shows there is an interaction effect between preference, consideration, and interest for made in products produced by the country The research also find out that mega projects also affect overall image of the country indirectly and the preference, consideration and interest for a given country offer affected by the overall national image. Based on this, the researchers recommends that;

$>$ Government shall consider mega projects a means of promotion tools to brand made in Ethiopia products

$>$ The concerned stakeholders and government officials shall focus both on the expansion and communication of those mega projects to the global stakeholders, development partners and investors, and visitors that in turn affects how they see the nation and its offers and affects the nation image in general

$>$ The country brand image management shall aim to create a unique, concise and differentiating representation of the nation. This image must enlighten the truth for both the country's citizens and the external audience.

\section{Reference}

[1]Klein JG, Ettenson R, Morris MD. The animosity model of foreign product purchase: An empirical test in the People's Republic of China. Journal of marketing. 1998 Jan;62(1):89-100.

[2]Maheswaran D, Chen CY. Nation equity: incidental emotions in country-of-origin effects. Journal of consumer research. 2006 Nov 14;33(3):370-6.

[3]Hooley GJ, Shipley D, Krieger N. A method for modelling consumer perceptions of country of origin. International marketing review. 1988 Mar 1;5(3):67-76.

[4]Kang M, Yang SU. Comparing effects of country reputation and the overall corporate reputations of a country on international consumers' product attitudes and purchase intentions. Corporate Reputation Review. 2010 
Mar 1;13(1):52-62.

[5]Lee JE, Jeon JE, Yoon JY. Does brand experience affect consumer's emotional attachments. Korean Journal of Marketing. 2010;12(2):53-81.

[6]Kunczik M. Globalisation: News media, images of nations and the flow of international capital with special reference to the role of rating agencies. Journal of International Communication. 2002 Jun 1;8(1):39-79.

[7]Agba MS, Agba AO, Ushie EM, Akwara AF. Poverty, Food Insecurity And The Rebranding Question in Nigeria. Canadian social science. 2009 Nov 1;5(6):1.

[8]Aaltonen K, Kujala J. A project lifecycle perspective on stakeholder influence strategies in global projects. Scandinavian journal of management. 2010 Dec 1;26(4):381-97.

[8]Dolea A. The need for critical thinking in country promotion: Public diplomacy, nation branding, and public relations. InThe Routledge handbook of critical public relations 2015 Aug 11 (pp. 298-312). Routledge.

[9]Ericksen MK. Using self-congruity and ideal congruity to predict purchase intention: A European perspective. Journal of Euromarketing. 1997 Jan 10;6(1):41-56.

[10]Fishbein M, Jaccard J, Davidson AR, Ajzen I, Loken B. Predicting and understanding family planning behaviors. InUnderstanding attitudes and predicting social behavior 1980. Prentice Hall.

[11]Foxall GR. Foundations of consumer behaviour analysis. Marketing theory. 2001 Jun;1(2):165-99.

[12]Bollen KA. A new incremental fit index for general structural equation models. Sociological Methods \& Research. 1989 Feb;17(3):303-16.

[13]Hair JF, Anderson RE, Tatham RL, William C. Black (1998), Multivariate data analysis. 